Jacek Puchalski

Warszawa

\title{
Interdyscyplinarne znaczenie badań nad bibliotekami powszechnymi dzialającymi w okresie II Rzeczypospolitej ${ }^{1}$
}

Odzyskanie niepodległości przez Polskę w 1918 r. i scalenie w jeden organizm państwowy ziem trzech zaborów stworzyło nową sytuację dla polskiej książki i bibliotek różnych typów, w tym powszechnych (zarówno samorządowych jak i społecznych), nazywanych również oświatowymi i publicznymi².

Okres dwudziestolecia międzywojennego to czas olbrzymiego wysiłku, zarówno państwa, jak i instytucji oraz organizacji społecznych, zmierzającego do podniesienia edukacji, oświaty i kultury społeczeństwa polskiego - hamowanego przez różne czynniki, od politycznych po gospodarcze.

Istotną rolę odgrywał niski poziom wykształcenia ludności. W $1921 \mathrm{r}$. w Polsce było ok. 33\% analfabetów, w 1931 r. - ok. 23\%, a w 1939 r. ok. 20\%3. Stopień analfabetyzmu był różny w poszczególnych regionach kraju. Na ziemiach dawnego zaboru pruskiego wskutek masowej scholaryzacji był minimalny, np. Śląsk miał najniższy ok. 1,6\% w 1931 r., natomiast na wschodnich obszarach II RP wskaźnik analfabetyzmu był bardzo wysoki ${ }^{4}$.

Pomimo wydania w $1919 \mathrm{r}$. dekretu $O$ obowiazku szkolnym, wprowadzającego 7-letnią szkołę powszechną dla wszystkich dzieci od 7 do 14 roku życia, do roku szkolnego 1922/23 nauczaniem początkowym objęto tylko część dzieci: od ok. $35 \%$ w województwach wschodnich do ok. $95 \%$ w zachodnich. Dopiero w roku szkolnym 1937/38 już ponad $90 \%$ dzieci było objętych obowiazkiem szkolnym. Należy podkreślić, iż nie do końca udało się utworzenie sieci 7-letnich szkól powszechnych, zapewniających pełną, podstawową edukację szkolną. Dominowały, szczególnie na wsiach, szkoły nie realizujące pełnego programu nauczania. Ten stan rzeczy usankcjonowała ustawa z $1932 \mathrm{r}$. (tzw. reforma jędrzejewiczowska), która utrzymując 7-letni obowiązek szkolny w zakresie

\footnotetext{
${ }^{1}$ Niniejszy artykuł wykorzystuje m.in. fragmenty opublikowane w mojej książce Źródła do historii bibliotek $w$ Polsce w latach 1918-1947. Studium bibliologiczne, Warszawa 2007.

${ }^{2}$ Szerzej na temat uwarunkowań działalności bibliotek w II RP zob. m.in. w: Z. Gaca-Dąbrowska, Bibliotekarstwo Il Rzeczypospolitej. Zarys problemów organizacyjnych i badawczych, Warszawa 2007.

${ }^{3}$ B. Bieńkowska, Ksiażka na przestrzeni dziejów, przy współpr. E. Maruszak, Warszawa 2005, s. 236.

${ }^{4}$ „Maly Rocznik Statystyczny”, 1937, s. 28-29.
} 
szkoły powszechnej, zachowała zróżnicowanie organizacyjne i programowe placówek ustanawiając szkoły powszechne I, II i III stopnia (4, 6 i 7-mio klasowe). Było to istotne m.in. $z$ punktu widzenia czytelnictwa, gdyż jak stwierdzil Janusz Kostecki „czytelnikami stawała się [...] młodzież, która ukończyła co najmniej 4-5 klas szkoły podstawowej, a zdolność do samodzielnego poruszania się w świecie piśmiennictwa zyskiwali [...] absolwenci szkół średnich”. Odnośnie wychowawczej roli szkolnictwa warto przypomnieć, że po przewrocie majowym 1926 r. ukształtował się „dopasowany” do rządów autorytarnych program tzw. wychowania państwowego, wymagający od szkól powiązania pracy dydaktycznej $z$ wychowaniem dzieci w duchu poszanowania władzy - państwa. Koncepcja ta spotkała się z krytyką zarówno opozycji lewicowej jak i prawicowej oraz ze strony mniejszości narodowych, które widziały w niej zagrożenie dla swych praw i interesów ${ }^{6}$.

Mimo różnorodnych trudności, ekonomicznych i wynikających $z$ poziomu rozwoju ruchu wydawniczego, w Polsce nastapil jednak ogromny wzrost krajowej produkcji wydawniczej. W okresie międzywojennym średnio wydawano ponad 6000 tyt. rocznie, „Z tendencją wzrostową". W „pocz. XX w. analogiczna średnia wynosila ok. 3000 tyt." . W 1938 r. ukazało się ok. 8700 publikacji w ponad 29 mln egzemplarzy.

Glód słowa drukowanego w coraz szerszym zakresie zaspokajała prasa, o czym świadczą dane, według których w 1918 r.na 1000 mieszkańców przypadało kilkanaście egzemplarzy prasy, a w 1938 r. już 61. Według J. Kosteckiego ok. 3 mln czytelników sięgało po periodyk przynajmniej raz w tygodniu 8 . Periodykom, czy w ogóle słowu drukowanemu, przypisywano dużą rolę w procesie oświaty. Dowodzą tego międzywojenne badania socjologiczne ${ }^{9}$ oraz czytelnictwa ${ }^{10}$ jak i świadectwa przedstawicieli różnych grup spolecznych. „Kiedy dowiedziałem się, że Andrzej Peda [ówczesny prezes Zarządu Powiatowego PSL „Wyzwolenie” w Sierpcu] posiada wszystkie roczniki „Zarania” [tygodnika wydawanego w Warszawie w latach 1907-1915], nie omieszkałem osobiście $z$ nich skorzystać. Wypożyczyłem je, wyczytałem dokładnie i muszę przyznać, że była to dla mnie lektura niezmiernie cenna, a już szczególnie artykuły [Tomasza] Nocznickiego, pełne pasji, nawołujące chłopów do oświaty, powszechnego czytelnictwa pożytecznych książek" - wspomina Kazimierz German, sekretarz kola Związku

${ }^{5}$ J. Kostecki, Dzieje czytelnictwa w Polsce (do roku 1945), w: Ludzie i ksiazki. Studia historyczne, pod red. J. Kosteckiego, Warszawa 2006, s. 28.

${ }^{6}$ Zob. m.in.: J. Sadowska, Ku szkole na miarę Drugiej Rzeczypospolitej. Gencza, zalożenia i realizacja reformy Jedrzejewiczowskiej, Bialystok 2001.

${ }^{7}$ J. Kostecki, Dzieje czytelnictwa..., s. 28.

${ }^{8}$ Tamże.

${ }^{9}$ M.in. Józefa Chałasińskiego, zob.: Mtode pokolenie chtopów, procesy i zagadnienia ksztaltowania sį̨ warstwy chtopskiej $w$ Polsce, t. 3: Rola kót mtodzieży wiejskiej w spoteczno-kulturalnych przeobrażeniach wsi. Warszawa 1938, s. 60-114, [Rola ksiażki w spoteczno-kulturalnej strukturze Kola].

${ }^{10} \mathrm{Z}$ publikacji na ten temat w ostatnich latach zob. A. Zdanowicz, Badania nad czytelnictwem wokresie II Rzeczypospolitej, w: Ludzie i ksiqziki..., s. 181-202. 
Młodzieży Wiejskiej „Siew” w Grodkowie-Morgach, opisując organizację biblioteki kola i kurs kulturalno-oświatowy w $1926 \mathrm{r}^{11}$.

Wedug J. Kosteckiego zbiorowość czytelników ksiazżek była czterokrotnie mniejsza niż zbiorowość odbiorców periodyków i składała się przede wszystkim $z$ inteligencji (ok. 40\%) oraz studentów i uczniów klas wyższych (ok. 20\%) ${ }^{12}$.

\section{Społeczna rola bibliotek powszechnych}

Zasygnalizowane powyżej czynniki wpływały na działalność bibliotek powszechnych w II RP. Swoją rolę odegrały tutaj również inne uwarunkowania, np. relatywnie wysokie ceny książek. Wedle wielu międzywojennych przekazów źródłowych biblioteka stawała się niezbędna w sytuacji, gdy „trudno jest w dzisiejszych czasach pomyśleć o tem, aby każda $z$ nas pojedynczo mogła sobie zakupić potrzebne ksiazżki. Ale zbiorowym wysiłkiem - organizacyjnie można tę trudność łatwo pokonać. W naszych organizacjach, w bibliotekach organizacyjnych, i w ogóle w bibliotekach powstających na wsi i dla wsi nie może zabraknąć książek, które nas obchodzą i które są nam potrzebne" czytamy w „Wiciach”, czasopiśmie Związku Młodzieży Wiejskiej Rzeczypospolitej Polskiej (ZMW RP „Wici”) ${ }^{13}$. Taki sposób widzenia zadań bibliotek był charakterystyczny dla wielu organizacji spolecznych, co dobrze obrazuje hasło placówki koła Narodowej Organizacji Kobiet (NOK) z Opatówka, utworzonej w 1924 r.: „Książka w organizacji to jak miecz na wojnie, zwyciężą ci, którzy garna się do ksiązki i potrafią $z$ niej korzystać"14. Dla wielu mlodych ludzi aktywność w organizacji odgrywała ważną rolę w procesie kształtowania ich osobowości: „tylko przez należenie do organizacji zmienilem kierunek drogi po której iść zacząłem, a czynny udział w życiu organizacji wpłynął całkowicie na bieg moich zainteresowań, dążeń i na mą działalność [...] dziś dla mnie organizacja jest jakby drugą rodziną, w której [...] nauczyłem się myśleć i żyć jak na człowieka przystało”, pisał członek koła ZMW RP „Wici”.

Sytuacja oświatowa, kulturalna, spoleczna, polityczna, ekonomiczna, a także narodowościowa niepodlegkej Polski stawiała więc przed prasą i książką - jako stosunkowo najłatwiej ówcześnie dostępnymi mediami, zwłaszcza na wsi, gdzie zasięg radia i filmu byl mały - zadanie podstawowego udzialu w procesach wychowania, samoksztalcenia, emancypacji i zdobywania awansu kulturowego

${ }^{11}$ K. German, Droga do celu, Wrocław 1979, s. 58-61.

12 J. Kostecki, Dzieje czytelnictwa..., s. 28.

${ }^{13}$ B. Baranówna, Czytajmy, „Wici”, 1936, nr 43, s. 46, cyt. za M. Olczak-Kardas, Popularyzacja książki i biblioteki w spoteczności wiejskiej w latach 1918-1939 (na przyktadzie województwa warszawskiego), „Studia Kieleckie. Seria Bibliologiczno-Prasoznawcza", 2002, nr 2, s. 19.

${ }^{14}$ Cyt. za D. Nowakowska, Narodowa Organizacja Kobiet, „Opatowianin”, luty-lipiec-sierpień 1995, [dok. elektroniczny] <http://www.biblioteka.opatowek.pl/002/hist0006/orks0003.html>, [dostęp: 03.02.2007].

${ }^{15}$ J. Chałasiński, Mlode pokolenia..., t. 3: Rola kót mlodzieży wiejskiej..., s. 31. 
i społecznego przez środowiska zapóźnione, głównie wiejskie, ale także robotnicze i rzemieślnicze. Biblioteka zaś bywała postrzegana jako ośrodek oświatowego, kulturalnego i wychowawczego oddziaływania nie tylko na pojedynczego czytelnika, ale i na całe grupy społeczne. Taki pogląd propagowała Helena Radlińska, twórczyni polskiej szkoły pedagogiki społecznej, kierownik Studium Pracy Społeczno-Oświatowej Wolnej Wszechnicy Polskiej w Warszawie (zał. w 1925 r.). W jej opinii biblioteka powinna pełnić funkcje placówki oświatowej mocno osadzonej w środowisku swojego działania, wspomagającej czytelnika w „rozwijaniu uzdolnień i przezwyciężaniu trudności w pracach samokształceniowych, w zdobywaniu sztuki wartościowania i wyboru, musi dopomóc jednostce $w$ identyfikacji jej dążeń $z$ dorobkiem ogólnym przez ułatwienie zdobywania wiedzy i umiejętności”16.

Dla wielu środowisk biblioteka miała być więc ośrodkiem szerzenia oświaty, kultury, idei spolecznych i politycznych. Szczególną rolę w tym kontekście przypisywano bibliotekom powszechnym. Dlatego liczbę placówek utworzonych przez organizacje dzialające jeszcze przed $1914 \mathrm{r}$. - przede wszystkim przez Polską Macierz Szkolną (PMS) ${ }^{17}$, Towarzystwo Czytelni Ludowych (TCL ${ }^{18}$ czy Towarzystwo Szkoły Ludowej (TSL) ${ }^{19}$ - powiększyły biblioteki zakładane przez towarzystwa, stowarzyszenia, związki i inne organizacje: kulturalne, oświatowe, polityczne i zawodowe, powstale po 1918 r., takie jak m.in. Towarzystwo Uniwersytetu Robotniczego (TUR - zał. w 1923 r.; 395 bibliotek i czytelń w 1937 r.), Centralny Związek Młodej Wsi (zal. w 1934 r.; 3285 bibliotek w 1937 r.) oraz ZMW RP „Wici” (zal. w 1928 r.; 1932 biblioteki w 1937 r.) ${ }^{20}$.

Analizując społeczną rolę bibliotek powszechnych w II RP nie można ograniczyć się do działalności największych stowarzyszeń, ogólnokrajowych i regionalnych, polskich i mniejszości, takich jak np.: ukraińskie Towarzystwo „Proswita” czy żydowskie Stowarzyszenie Oświatowo-Kulturalne „Tarbut”. Należy mieć świadomość, że w skali lokalnej biblioteki tego typu prowadzone były przez wiele podmiotów. Przykładem może być powiat hrubieszowski, gdzie według publikacji Biblioteki oświatowe. Spis na dzień 1 stycznia 1930 r. działały placówki m.in.: Kół Młodzieży Wiejskiej, kółek rolniczych, ukraińskie (Stowarzyszenie „Ridna Chata”), Związku Kupców, organizacji żydowskich (Żydowska Organizacja Skautowa „Haszomer Hacair”), związków zawodowych (Związek Zawodowy Robotników Przemysłu Odzieżowego, Związek Zawodowy Robotników Niefa-

\footnotetext{
${ }^{16}$ I. Lepalczyk, Pedagogika biblioteczna Heleny Radlińskiej, Łódź 1974, s. 65.

${ }^{17} 37381$ czlonków i 2386 bibliotek w 1938 r., zob. A. Grefkowicz, Polska Macierz Szkolna, w: Stownik polskich towarzystw naukowych, t. II: Towarzystwa naukowe i upowszechniajq̨ce naukę dziatajq̨e $w$ przesztości na ziemiach polskich, Cz. 1, red. nauk. B. Sordylowa, oprac. zespół pod kier. B. Krajewskiej-Tartakowskiej, Wroclaw 1994, s. 446.

${ }^{18} 15000$ członków, 257 kół w 1936 r., 1651 bibliotek i czytelń w latach 1936/1937, zob. „Mały Rocznik Statystyczny", 1939, s. 351.

${ }^{19} 43000$ czlonków w 1937 r., 2647 bibliotek w latach 1936/1937, zob. tamże.

${ }^{20}$ Tabl. nr 24 pt. Niektóre Stowarzyszenia Oświatowo-Kulturalne, „Mały Rocznik Statystyczny”, 1939, s. 351; tabl. nr 25 pt. Niektóre Stowarzyszenia Wyższej Użyteczności, tamże, s. 352.
} 
chowych, Klasowy Związek Zawodowy), Stowarzyszenia Młodzieży Polskiej i Związku Nauczycielstwa Polskiego ${ }^{21}$.

Organizacje społeczne - prowadzące i utrzymujące biblioteki - reprezentowały cały wachlarz poglądów, postaw ideologicznych i politycznych: od komunistycznych po skrajnie prawicowe. $Z$ punktu widzenia ich stosunku do książki i biblioteki można je podzielić na patronackie (np. PMS) i na organizacje „o charakterze emancypacyjnym (np. «Wici»), propagujące wzór instrumentalnego traktowania tekstów"22. Oba typy podmiotów przeżywały w okresie międzywojennym trudności organizacyjne, materialne i merytoryczne.

Organizacje borykając się często $z$ brakiem środków finansowych, wykwalifikowanej kadry biblioteczne ${ }^{23}$ i problemami lokalowymi, dbały przede wszystkim o właściwą tematykę - np. pod względem ideowym - swoich księgozbiorów, zwracając zaś mniejszą uwagę na ich profesjonalną organizację czy aktualizacje zbiorów ${ }^{24}$. Przy doborze wydawnictw do takich księgozbiorów duże znaczenie miały spisy oraz omówienia literatury publikowane na lamach czasopism poszczególnych organizacji, a także serie wydawnicze ${ }^{25}$. Przykładem może być Poradnik Biblioteczny Zjednoczenia Polskich Towarzystw Oświatowych. Miesięcznik utatwiajacy wybór książek dla bibliotek, publikowany w latach 1931-1939 przez TCL pod redakcją Józefa Stemlera, jako dodatek do czasopisma „Oświata Polska”. Jak dowodza badania Grażyny Gzelli nad bibliotekami ZMW RP „Wici” centrale niektórych organizacji starały się bezpośrednio wpływać na zawartość

\footnotetext{
${ }^{21}$ Warszawa 1932, s. 52-53.

${ }^{22}$ J. Kostecki, Dzieje czytelnictwa..., s. 28.

${ }^{23}$ Zob. m.in.: M. Olczak-Kardas, Pracownicy bibliotek wiejskich w województwie warszawskim w latach 1918-1939, „Roczniki Biblioteczne”, 2008, s. 95-114.

${ }^{24}$ Np. wedle kroniki i protokolów zebrań NOK z Opatówka w 1934 r. członkinie organizacji nie korzystały ze swojej biblioteki, zob. D. Nowakowska, Narodowa Organizacja Kobiet...

${ }_{25}$ Było to możliwe m.in. dzięki dzialalności wyspecjalizowanych wydawnictw (zob. N. Kraśko. Instytucje wydawnicze w II Rzeczypospolitej, Warszawa 2001) i publikacji serii wydawniczych. Wedlug cytowanych przez Artura Jazdona obliczeń Janusza Dunina (Rozwój cech wydawniczych polskiej ksiazzki literackiej XIX i XX wieku, Łódź 1982) w latach 1900-1939 w Polsce ukazalo się 600 serii literackich. Aniela Morawska (Serie wydawnicze w Polsce Ludowej, Warszawa 1971) „wskazuje na fakt swoistej eksplozji w latach 19181939 różnego typu pomysłów edytorskich w tym zakresie. Oprócz serii naukowych rozpoczynających się od słów: Archiwum..., Badania..., Monografie..., Prace... doliczyła się autorka przeszło 180 serii naukowych i popularnonaukowych zatytułowanych Biblioteka..., przeszło 40 popularnych pt. Biblioteczka..., a obok nich przeróżne serie dla: emigrantów, wsi, miast, «dobrych książek», branżowe, samorządowe, skarbowe, kresowe, regionalne, poetyckie, urzędnicze, wieczornicowe, z zakresu higieny, życia codziennego, kursów korespondencyjnych itp.". Sam A Jazdon wyróżnia (m.in. na podstawie Katalogu polskich wydawnictw seryjnych $i$ biblioteczek szkolnych $w$ uktadzie alfabetycznym wedtug tytutów, Warszawa 1938) wśród wielkopolskich serii wydawniczych, opublikowanych do 1945 r., grupy tematyczne: literackie, religijne, historyczno-biograficzne, teatralne, gospodarcze i ekonomiczno-rolnicze, społeczne, pedagogiczne, muzyczne, społeczno-polityczne, medyczne, rolnicze, oświatowe, polityczne i pozostale. Zob. A Jazdon: Wielkopolskie serie wydawnicze do 1945 roku, Poznań 1997, [dok. elektroniczny] <http://lib. amu.edu.pl/serie/>, [dostęp: 15.09.2006].
} 
księgozbiorów, m.in. poprzez odpowiednie uchwały ${ }^{26}$, tworzenie własnych księgarń ${ }^{27}$ oraz firmowanie poradników bibliotecznych ${ }^{28}$. Zarządy organizacji próbowały się także orientować w zawartości księgozbiorów i w funkcjonowaniu swoich placówek. Najczęstszą formą nadzoru byl wymóg składania sprawozdań przez biblioteki. Przy czym w przypadku dużych organizacji, takich jak ZMW RP „Wici”, sprawozdania $z$ bibliotek poszczególnych kół ujmowano zbiorczo, na szczeblu powiatowym, okręgowym, wojewódzkim i centralnym ${ }^{29}$. Kolejnym sposobem realizacji nadzoru była ankietyzacja zmierzająca do określenia stopnia wykorzystania księgozbiorów i zbadania preferencji czytelniczych wśród członków organizacjijo.

Szczególną rolę spełniały biblioteki powszechne mniejszości narodowych, jako ośrodki podtrzymujące i rozwijające tożsamość narodową. Przy czym dla społeczności niemieckiej, ukraińskiej ${ }^{31}$, czy świadomych narodowo środowisk białoruskich $^{32}$ biblioteki były elementem realizacji praw mniejszości, zagwarantowanych przez Mały Traktat Wersalski ${ }^{33}$ oraz Konstytucję $z 17$ marca $1921 \mathrm{r}^{34}$,

\footnotetext{
${ }^{26} \mathrm{~Np}$. Walny Zjazd ZMW RP,Wici” wezwał wszystkie koła do prenumerowania organu związkowego. Zob. Prasa w zbiorach bibliotecznych kót młodzieży wiejskiej CZMW $i$ ZMW RP, Wici” oraz jej czytelnictwo (1919-1928-1939), w: Studia o bibliotekach $i$ zbiorach polskich, t. 2, Toruń 1992, s. 23.

${ }^{27}$ Związek Młodzieży Wiejskiej „Znicz” w Krakowie zorganizowal księgarnie „niezbędną do prawidłowej pracy kół". Zob. G. Gzella: Zbiory ksiażek $i$ najpoczytniejsze tytuły $w$ bibliotekach kót mtodzieży wiejskiej CZMW i ZMW RP „Wici”, w: Studia o bibliotekach..., t. 1, Toruń 1991, s. 32.

${ }^{28}$ Np. wydawnictwo PMS: M. Małachowska, A. Reiterowa, Poradnik biblioteczny. Katalog utatwiajacy wybór ksiq̨zek w bibliotekach oświatowych, Warszawa 1935.

${ }^{29} \mathrm{G}$. Gzella, Zbiory ksiqziek.... s. 30-41.

${ }^{30}$ Tamże, s. 35.

${ }^{31}$ Zob. m.in.: M. Iwanicki, Oświata i szkolnictwo ukraińskie w Polsce w latach 1918-1939, Siedlce 1975.

${ }^{32} \mathrm{O}$ znaczeniu, jakie przypisywały bibliotekom te środowiska świadczy Rezolucja $w$ sprawie szkolnej prayjęta na Zjeździe Wtościaństwa Bialoruskiego oraz organizacji i partii Zachodniej Białorusi, który odbył się 11-12 grudnia 1921 r. w Wilnie. Punkt 11 Rezolucji brzmiał: „Swoboda dla stawiania spektakli bialoruskich i wolność wydawnictw i utworów kulturalno-oświatowych, a także otwarcie bibliotek i czytelni”. Cyt. za J. Januszewska-Jurkiewicz, Dwie „krajowe” inicjatywy biatoruskie na Litwie Środkowej, „Białoruskie Zeszyty Historyczne”, nr 16, [dok. elektroniczny], <http://kamunikat.fontel.net/www/czasopisy/bzh/16/16kryn_januszewska.htm>. [dostęp: 10.11.2006].

${ }^{33}$ Art. 8. Traktatu glosil: „Obywatele polscy należący do mniejszości etnicznych, religijnych lub językowych [...] będą mieli równe prawa do zakladania, prowadzenia i kontrolowania własnym kosztem instytucji dobroczynnych, religijnych lub spolecznych, szkół i innych zakładów wychowawczych oraz prawo swobodnego używania w nich języka”. Art. 9.: „W miastach i okręgach, zamieszkałych przez znaczny odłam obywateli polskich należących do mniejszości etnicznych, religijnych lub językowych, mniejszościom tym zostanie zapewniony sluszny udział w korzystaniu oraz w przeznaczaniu sum, które budżet państwowy, budżety miejskie lub inne przyznają $\mathrm{z}$ funduszów publicznych na cele wychowawcze, religijne lub dobroczynne”. Zob. „Dz. U. RP”, 1920, nr 110, poz. 728; K. Kierski, Ochrona praw mniejszości w Polsce, Poznań 1933; W. Sworakowski, Międzynarodowe zobowiązania mniejszościowe Polski, Warszawa 1935.

${ }^{34}$ „Art. 109. Każdy obywatel ma prawo zachowania swej narodowości i pielęgnowania swojej mowy i właściwości narodowych. Osobne ustawy państwowe zabezpieczą mniejszościom w Państwie Polskim pełny i swobodny rozwój ich wlaściwości narodowościowych przy pomocy autonomicznych związów mniejszości o charakterze publiczno - prawnym w obrębie związków samorządu powszechnego.
} 
powtórzonych w Konstytucji z 23 kwietnia 1935 r. i w innych aktach prawnych ${ }^{35}$. Stanowiły niekiedy narzędzie walki z polonizacją, czy repolonizacją ludności autochtonicznej, ale także, przede wszystkim w przypadku bibliotek niemieckich i ukraińskich, były traktowane jako jedne $z$ instytucji symbolizujących w pewien sposób autonomiczność, odrębność terenów objętych ich działalnością. Co więcej według Marka Andrzejewskiego działalność bibliotek mniejszości niemieckiej stanowi dowód na zwiazzek między narodowo-kulturalnymi aspiracjami mniejszości i jej dążeniami politycznymi, a celami III Rzeszy: „Stosunkowo duże zainteresowanie Berlina działalnością niemieckich bibliotek w Polsce mialo w dużym stopniu podłoże natury politycznej. Było obliczone na utrzymanie wśród mniejszości niemieckiej poczucia jej odrębności kulturowej i przeciwdziałanie procesowi repolonizacji i polonizacji. Zamierzeniom tym służyły dotacje finansowe, bezpłatne przesylki z książkami, szkolenie górnośląskich bibliotekarzy w Niemczech. Bez pomocy z Rzeszy niemieckie biblioteki na Górnym Śląsku i na pozostałym obszarze Rzeczypospolitej znalazłyby się w trudnej sytuacji, a część z nich musiałaby zaprzestać prowadzenia działalności”36. Stąd dla administracji polskiej biblioteki mniejszości bywały przedmiotem zainteresowania z punktu widzenia ewentualnych zagrożeń dla państwa.

\section{Biblioteki powszechne - skala ilościowa zjawiska}

O wadze, jaką przywiązywały organizacje społeczne do działalności bibliotecznej, świadczą dane spisu Biblioteki oświatowe..., według których w 1929 r. były one wlaścicielami ponad $80 \%$ wszystkich bibliotek i biblioteczek tego typu. Jak stwierdza Barbara Bieńkowska większość $\mathrm{z}$ nich mieściła się na wsiach (ok. $60 \%$ ) i była „słabo zaopatrzona w książki”, posiadając księgozbiory liczące od 100 do 500 tomów ${ }^{37}$.

Szacując liczbę bibliotek powszechnych należy pamiętać, że dane uzyskiwane podczas oficjalnych spisów bibliotek w okresie międzywojennym były zazwyczaj niepelne w skutek niechęci właścicieli placówek do ich rejestracji. Informuje o tym m.in. fragment sprawozdania $z$ rejestracji bibliotek przez Ministerstwo Wyznań Religijnych i Oświecenia Publicznego (MWRiOP) w 1929 r.: „Inspektorzy [szkolni] donosili, iż mimo trzykrotnego zwracania się nie można

Państwo będzie miało $w$ stosunku do ich dzialalności prawo kontroli oraz uzupelnienia w razie potrzeby ich środków finansowych. Art. 110: Obywatele polscy, należący do mniejszości narodowościowych, wyznaniowych lub językowych mają równe $z$ innymi obywatelami prawo zakładania, nadzoru i zawiadywania swoim własnym kosztem zakładów dobroczynnych, religijnych i społecznych, szkół i innych zakładów wychowawczych oraz używania w nich swobodnie swej mowy i wykonywania przepisów swej religii". Zob. „Dz. U. RP”, 1921, nr 49, poz. 267.

${ }^{35}$ Zob. m.in.: L. Zieleniewski, Ustawodawstwo jezykowe Rzeczypospolitej Polskiej, Warszawa 1930.

${ }^{36}$ M. Andrzejewski, Uwagi o bibliotekach mniejszości niemieckiej $w$ województwie ślqaskim $w$ latach 1922-1939, „Roczniki Biblioteczne”, 32:1988, z. 2, s. 121-122.

${ }^{37}$ B. Bieńkowska, Książka na przestrzeni..., s. 239. 
było otrzymać od niektórych instytucyj wypelnionych kwestjonarjuszy [...]. W pewnej liczbie wypadków dopiero interwencja władz administracyjnych skłoniła zarząd bibljoteki do nadesłania wypełnionego kwestjonarjusza. Trudności te powstały wskutek niezrozumienia potrzeby i znaczenia rejestracji, oraz niekiedy wskutek niechęci wypełniania kwestjonarjuszy. Do tej kategorji należy sporo Stowarzyszeń Młodzieży Polskiej, które odmawiały wypełnienia kwestjonarjuszy mimo przychylnego stanowiska ich centrali - Zjednoczenia Młodzieży Polskiej; nie można było również uzyskać informacyj od wielu kół Tow. Czytelni Ludowych i niektórych oddzialów Tow. Uniwersytetu Robotniczego"38. Ostatecznie część bibliotek oświatowych nie została zapewne objęta rejestracją MWRiOP.

O tym jak mało precyzyjne mogą być informacje statystyczne świadczą dane za rok 1937/38 na temat bibliotek powszechnych opublikowane w „Małym Roczniku Statystycznym" z 1939 r. Według Głównego Urzędu Statystycznego (GUS) liczba ruchomych i stałych bibliotek oświatowych wynosila w sumie 8098 placówek działających w latach 1937/1938 ${ }^{39}$. Jednak analiza kolejnych tablic „Małego Rocznika” pozwala stwierdzić, że w latach 1936/1937 r. organizacje społeczne prowadziły lącznie co najmniej 16576 stałych i ruchomych bibliotek oraz czytelni. Przy czym w tablicach odnoszących się do Stowarzyszeń Oświatowo-Kulturalnych ${ }^{40}$ i Stowarzyszeń Wyższej Użyteczności ${ }^{41}$ odnotowano biblioteki oświatowe prowadzone przez wybrane organizacje, pomijając inne. Na przykład pominięto organizacje mniejszości narodowych, w tym ukraińskie Towarzystwo „Proswita”, które jak podaje „IV Ukrainskij Statisticnij Ricnik 19361937" w 1935 r. prowadziło 2915 bibliotek $^{42}$ (samo Towarzystwo podawało dla 1934-1935 r. liczbę 2922 bibliotek i 3046 czytelni ${ }^{43}$ ).

Ponieważ źródłem informacji dla GUS były sprawozdania poszczególnych organizacji społecznych ${ }^{44}$, cytowane powyżej dane liczbowe należy traktować z największą ostrożnością, choćby ze względu na ich potencjalną tendencyjność. Taką ocenę uzasadniaja np. dane na temat bibliotek Towarzystwa „Proswita” ukazujące siłe ,żywiołu" ukraińskiego na Kresach Wschodnich II RP45 czy dane polskiego Towarzystwa Rozwoju Ziem Wschodnich wyrazające tendencję przeciwstawną ${ }^{46}$.

${ }^{38}$ Biblioteki oświatowe..., s. VIII-LX.

39 „Maly Rocznik Statystyczny", 1939, s. 342.

${ }^{40}$ Tamże, s. 351.

${ }^{41}$ Tamże, s. 352.

${ }^{42}$ S. 284.

${ }^{43}$ Dziatalność Towarzystwa „Proswita”, „Sprawy Narodowościowe”, 1935, nr 5, s. 458.

44 „Mały Rocznik Statystyczny”, 1939, s. 351.

${ }^{45} \mathrm{Na}$ temat roli bibliotek w oświatowej działalności mniejszości ukraińskiej, zob. m.in.: M. Syrnyk, Ukraińcy w Polsce 1918-1939. Oświata i szkolnictwo, Wroclaw 1996, s. 118-119 i in.

${ }^{46}$ "Wedhug statystyki, Towarzystwo Rozwoju Ziem Wschodnich w 1938 r. prowadzilo 500 bibliotek", cyt. za Biblioteki na wschodnich ziemiach II Rzeczypospolitej. Informator, red. nauk. B. Bieńkowska, oprac. U. Paszkiewicz i in., Poznań 1998, s. 13. 
Specjalizujący się $\mathrm{w}$ dziedzinie bibliotek oświatowych Józef Janiczek $z$ Wydziału Oświaty Pozaszkolnej MWRiOP szacował, że w 1938 r. działało ponad 21000 bibliotek oświatowych - w tym ok. 10000 punktów bibliotecznych ${ }^{47}$.

Według do tej pory najpelniejszych i najrzetelniej źródłowo udokumentowanych, choć jednak fragmentarycznych, danych zebranych w latach $1993-2000^{48}$ przez Zespól ds. Bibliotek Biura Pelnomocnika Rządu do Spraw Polskiego Dziedzictwa Kulturalnego za Granicą Ministerstwa Kultury i Dziedzictwa Narodowego liczbę bibliotek powszechnych można określić na ok. 35000 placówek $^{49}$ wśród ok. 70000 bibliotek instytucjonalnych działających na terenie II RP ${ }^{50}$. Wydaje się, że ta liczba najbliżej oddaje rzeczywistą skalę zjawiska jakim były biblioteki powszechne $\mathrm{w}$ okresie międzywojennym. Naturalnie można mieć nadzieje, iż wraz z rozwojem badań stan naszej wiedzy, przynajmniej na temat ogólnej liczby bibliotek działających w Polsce i w jej poszczególnych regionach oraz jednostkach administracyjnych, będzie się pogłębiał.

\section{Interdyscyplinarne znaczenie badań nad historią bibliotek powszech- nych}

Powyższa, $z$ konieczności krótka charakterystyka bibliotek powszechnych $z$ okresu II RP sygnalizuje, $z$ jak wieloma i $z$ jak różnymi źródłami historyk bibliotek może mieć do czynienia. Jak niespodziewane mogą być motywacje ich twórców, wypadkową jak wielu układów i stosunków środowiskowych może być ich pochodzenie i autorstwo ${ }^{51}$. Źródla te mogą zatem dostarczać użytecznych informacji nie tylko o bibliotekach ale i na temat ich wlaścicieli oraz środowiska, w których działały. Pozwalają również na obserwację bibliotek „z zewnątrz”, m.in. $z$ punktu widzenia instytucji $z$ nimi wspólpracujących $i / l u b$ je nadzorujących. Umożliwiają tym samym określenie rzeczywistego znaczenia bibliotek wśród innych instytucji - kulturalnych, oświatowych, naukowych.

Wbadaniach natematrolibibliotekpowszechnych wokresiemiędzywojennym użyteczne mogą więc być nie tylko źródła wytwarzane przez wlaścicieli bibliotek

\footnotetext{
${ }^{47}$ J. Janiczek, Bibliotekarstwo oświatowe w Polsce po dwudziestu latach niepodlegtości, „Bibliotekarz”, 1939 , nr 1-2, s. I-7.

${ }^{48}$ Dla potrzeb publikacji: Wstępny raport o stanie wiedzy, red. nauk. A. Mężyński, Cz. 1, Analiza, oprac. B. Bieńkowska i in., Warszawa 1994; Biblioteki na wschodnich ziemiach; Informator o stratach bibliotek $i$ ksieggozbiorów domowych na terytoriach polskich okupowanych w latach 1939-1945 (bez ziem wschodnich), red. nauk. B. Bieńkowska, oprac. U. Paszkiewicz, J. Szymański, Poznań 2000.

${ }^{49}$ Podobna liczbe podawał Jan Muszkowski pisząc o „stwierdzonej statystycznie cyfrze ok. 35.000 bibliotek i biblioteczek na terenie Rzeczypospolitej", zob. Biblioteki oświatowe w Polsce. Odbitka z dzieła zbiorowego p.t. Ksiqzka w pracy oświatowej, Warszawa 1935, s. 14-15.

${ }^{50}$ B. Bieńkowska, Potyczki ze źródtami bibliologicznymi (na przyktadzie urzędowej dokumentacjì strat bibliotek w Polsce podczas II wojny światowej), „Roczniki Biblioteczne”, 2001, s. 24.

${ }^{51}$ Zob. J. Puchalski, Propozycja typologii źródel do historii bibliotek w Polsce w latach 1918-1947, w: Bibliologia. Problemy badawcze nauk humanistycznych, praca zbior. pod red. D. Kuźminy, Warszawa 2007, s. 297-309.
} 
oraz same biblioteki, ale równie istotne mogą się okazać dokumenty powstające w instytucjach działających w otoczeniu bibliotek. Mogą to być m.in. akta:

- kościelne różnych wyznań,

- instytucji państwowych (zwłaszcza kuratoriów okręgów szkolnych, inspektoratów szkolnych i urzędów wojewódzkich, przede wszystkim wydziałów społeczno-politycznych i oświecenia publicznego, starostw i policji).

- samorządowe (źródła dotyczące oświaty i szkolnictwa wytwarzane w gminach, radach i zarządach miejskich, sejmikach powiatowych i wojewódzkich),

- instytucji i organizacji spolecznych.

Warto zatem podjąć trud odtworzenia struktury społecznej i instytucjonalnej na terenie działania badanych bibliotek $w$ danym czasie oraz zidentyfikować te instytucje i organizacje, które bezpośrednio lub pośrednio rzutowały na ich funkcjonowanie (np. inne biblioteki, płatne wypożyczalnie, księgarnie, związki zawodowe, stowarzyszenia, partie polityczne itp.). Odtworzenie „mapy” instytucji i organizacji w danej miejscowości - m.in. przy wykorzystaniu propozycji Marii Kocójowej sformulowanych w artykule Metoda topograficzna $w$ badaniach nad ksiażka i bibliotekq ${ }^{52}$ czy Jerzego Plisa w tekście Spoteczne instytucje ksiqziki $w$ międzywojennym Lublinie ${ }^{53}$ - i prześledzenie zmian, jakie w nich następowały w poszczególnych okresach czasu, może dostarczyć przesłanek do odpowiedzi na pytania o to, czy i na ile powstanie, organizacja i działalność danej biblioteki wiązały się np. z:

- potrzebami społeczności lokalnej, lub jej poszczególnych grup;

- państwowymi, samorządowymi i społecznymi inicjatywami „zewnętrznymi” aktywizującymi działalność biblioteczną na danym terenie;

- realizacją celów statutowych poszczególnych organizacji względnie zaspokojeniem osobistych zainteresowań lub ambicji ich działaczy;

- charakterem miejscowości (przykładem może być działalność bibliotek w uzdrowiskach);

- rozwojem infrastruktury spolecznej miejscowości;

- świadomej polityki władz lokalnych;

- działalnością innych instytucji, w tym bibliotek ${ }^{54}$.

Rezultaty podobnych dociekań mogą być wykorzystane przy analizie problemów, które czekają jeszcze na swoich badaczy. Należą do nich m.in.:

\footnotetext{
${ }^{52}$ W: Studia bibliograficzno-bibliologiczne. Praca zbior. dla uczczenia 45-lecia pracy naukowej Profesora Wiestawa Bieńkowskiego, red. M. Kocójowa, Kraków 1995, s. 165-174.

${ }^{53}$ W: Lublin a ksiqżka. Materiaty z konferencïi naukowej, Lublin-Pszczela Wola, 6-7 listopada 2002 r., pod. red A. Krawczyka, E. Józefowicz-Wisińskiej, Lublin 2004, s. 585-598.

${ }^{54}$ Znaczenie racjonalnej organizacji sieci bibliotecznych, uwzględniającej charakter lokalnej i regionalnej struktury społecznej, podkreślano podczas IV Zjazdu Bibliotekarzy Polskich w Warszawie, m.in. w referatach Jana Augustyniaka Organizacja sieci bibliotek publicznych na terenie miasta prowincjonalnego [...], Stanislawa Gepperta Plan i realizacja powiatowej sieci bibliotecznej na przyktadzie powiatu lomżýnskiego oraz Piotra Maślankiewicza Plan i realizacja sieci wojewódzkiej na przykładzie Ślaska, zob.: IV Zjazd Bibliotekarzy Polskich w Warszawie dnia 31 maja - 2 czerwca 1936 roku. Referaty, Cz. 1, Warszawa 1936, s. 169-206.
} 
- udział samorządów w organizacji bibliotek ${ }^{55}$;

- sieci biblioteczne poszczególnych organizacji społecznych ${ }^{56}$;

- rola bibliotek w życiu mniejszości narodowych, grup etnicznych i wyznaniowych. Publikacji na ten temat jest mało. Zaniedbanym problemem badawczym pozostaje m.in. działalność bibliotek parafialnych ${ }^{57}$;

- historia bibliotek w ujęciu lokalnym ${ }^{58}$ i regionalnym ${ }^{59}$, zwlaszcza na terenach Kresów Wschodnich II RP, w tym rola bibliotek w życiu społecznym i kulturalnym „pogranicza”60.

To tylko część istotnych kwestii, których pełne opracowanie prowadziloby do syntezy dziejów bibliotek powszechnych w II RP. Bowiem mimo wielu prac, z publikacjami Jadwigi Kołodziejskiej na czele ${ }^{61}$, nasza obecna wiedza na ten temat nie jest wystarczająca, zważywszy na skalę i zlożoność zjawiska.

Z drugiej strony wśród źródel do historii bibliotek są materiały, które potencjalnie mogą okazać się użyteczne także dla badaczy reprezentujących inne dyscypliny niż bibliologia, zajmujących się np. różnymi dziedzinami życia społecznego, środowiskami, grupami spolecznymi i zawodowymi.

Przykładem takiego źródła może być Inwentarz Biblioteki parafialnej Kościoła rzymsko-katolickiego $w$ Turośni, sporządzony po 1930 r., przechowywany obecnie w Archiwum Archidiecezjalnym w Białymstoku ${ }^{62}$. Dokument ów może stanowić uzupełniające źródło do badań nad społecznością lokalną:

- jej stanem zdrowotnym w danym czasie ( $w$ inwentarzu znalazło się kilka broszurek na temat gruźlicy i jaglicy, wydanych w okresie I wojny światowej, kiedy ryzyko zachorowań wzrosło);

${ }^{55}$ Warto w tym kontekście odnotować artykul Moniki Olczak-Kardas, Biblioteki szkolne i publiczne wgminnych budżetach administracyjnych w latach 1918-1939 na przyktadzie powiatu rawskiego. ..Kieleckie Studia Bibliologiczne", 2000, t. 5, s. 61-79.

${ }^{56} \mathrm{O}$ użyteczności takich badań świadczą m.in. publikacje G. Gzelli poświęcone ZMW RP „Wici” - przede wszystkim Biblioteki i czytelnictwo w kotach mtodzieży wiejskiej CZMW i ZMW RP „Wici”, (19191928-1939), Toruń 1991.

${ }^{57}$ Do wyjątków należy artykuł J. Plisa, Biblioteki parafialne $w$ diecezji podlaskiej (1918-1939), „Z Badań nad Polskimi Księgozbiorami Historycznymi”, 1993, s. 209-217. Zob. także zarys problematyki w: A. Biernacka, M. Dubiński, Zarys historii bibliotek parafialnych w Polsce, „Archiwa, Biblioteki i Muzea Kościelne", 2000, t. 73, s. 9-20.

${ }^{58}$ Wśród najnowszych publikacji zwraca uwagę artykul Andrzeja Mężyńskiego Biblioteki Warszawy w 1939 roku, „Rocznik Biblioteki Narodowej”, 2008, s. 171-188.

${ }^{59} \mathrm{Z}$ publikacji, które ukazały się w ostatnich latach, można wymienić np. Biblioteki oświatowe w Lubelskiem (1918-1939) J. Plisa (Lublin 1999) czy Księgozbiory bibliotek wiejskich w województwie warszawskim w latach 1918-1939 M. Olczak-Kardas (Kielce 2007).

${ }^{60}$ Ostatnio ukazalo się kilka publikacji świadczacych o kontynuacji badań na ten temat, np. Centrum i pogranicze w polskiej kulturze wydawniczej i czytelniczej, pozycja wydana pod red. Elżbiety Gondek i Ireny Sochy (Katowice 2008).

${ }^{61}$ Publiczne biblioteki samorzqdowe w okresie międzywojennym, Warszawa 1967; Spoteczna funkcja biblioteki publicznej, Warszawa 1976; Lokalność i uniwersalność biblioteki, Warszawa 2000; Szerokie okno biblioteki, Warszawa $2006 \mathrm{i}$ in.

${ }^{62}$ Inwentarz Biblioteki parafíalnej Kościoła rzymsko-katolickiego w Turośni, w: A. Szot, Biblioteki parafialne i prasa katolicka archidiecezji wileńskiej w okresie międzywojennym, „Bibliotekarz Podlaski”, 2004, nr 8-9, [dok. elektroniczny] <http://www.wbp.bialystok.pl:81/9/szot.htm>, [dostęp: 15.09.2006]. 
- poziomem kultury rolnej (broszurki na temat hodowli i upraw);

- problemami spolecznymi (przede wszystkim alkoholizm - kilkanaście broszurek propagujących trzeźwość);

- sytuacją polityczną (broszurki antykomunistyczne, być może zwiazane $z$ dość aktywną działalnością na tym terenie KPZB - Komunistycznej Partii Zachodniej Bialorusi, zal. w 1923 r.).

Naturalnie, inwentarz może być zarówno odzwierciedleniem rzeczywistej sytuacji panującej w Turośni w poszczególnych okresach czasu, jak i odbiciem jej subiektywnej oceny przez twórcę księgozbioru biblioteki parafialnej. Ustalenie faktycznego stanu rzeczy wymaga poprawnego, naukowego odczytania i interpretacji nie tylko inwentarza, ale również wszystkich innych, dostępnych źródeł wytworzonych w środowisku biblioteki w Turośni- w sensie terytorialnym i społecznym: środowisko intelektualne, zawodowe, etniczne, wyznaniowe i polityczne. Chodzi tutaj zwłaszcza o źródła zawierające informacje na temat potencjalnych użytkowników placówki, m.in. ich wieku, płci, statusu społecznego, narodowości, wykształcenia, uczestnictwa w kulturze; aktywności społecznej, politycznej i zawodowej; a nawet stanu zdrowotnego.

Powyższy przykład obrazuje konieczność sięgania przez historyków bibliotek nie tylko do własnych, specyficznych źródeł i metod badawczych $-\mathrm{z}$ metoda proweniencyjną, bibliograficzną i typograficzną na czele - ale także do metod zaczerpniętych $\mathrm{z}$ innych nauk. Historia bibliotek musi więc korzystać $\mathrm{z}$ dorobku nauk historycznych, jak również z socjologicznych, ekonomicznych, filologicznych i innych, w przypadku, gdy jest to konieczne.

Oczywiście, należy zgodzić się $z$ poglądem, iż historyk bibliotek nie zawsze będzie w stanie we właściwy sposób odczytać i zinterpretować źródła, których zbadanie wymaga specjalistycznej wiedzy. Przy ich ocenie powinien wszakże korzystać $z$ dorobku innych dziedzin, jeśli takowy istnieje. $Z$ drugiej zaś strony źródla (np. inwentarze i katalogi książek) i metody bibliologiczne mogą być wykorzystywane w badaniach m.in. nad dziejami oświaty i kultury.

W dyskusjach środowiskowych podnoszony bywa postulat ścisłego rozgraniczania dziedzin naukowych, np. badań historycznych i bibliologicznych. Jednak badacz chcący rzetelnie wyjaśnić dany problem będzie korzystal ze wszystkich użytecznych źródeł odwołując się w razie konieczności do dorobku innych, niż macierzysta, dyscyplin wiedzy. Dlatego, jak zauważa Krzysztof Migoń, bywa, że np. problematyką bibliologiczną (księgoznawczą) zajmują się uczeni, dla których, ksiażka stanowi uniwersalne narzędzie przekazu tekstów piśmienniczych i/lub materialny obiekt możliwy do opisania w kategoriach pozabibliologicznych. Owi uczeni nie uważają się za bibliologów, ponieważ „o bibliologii często w ogóle nie słyszeli i sądzą nawet, że weszli w pole niczyje" ${ }^{63}$. Wydaje się, że „wchodzenie w nie swoje pole” może przynieść pożytek dla wszystkich

${ }^{63}$ K. Migoń, Kultura ksiązki. Program dla bibliologii i potrzeba dla studiów bibliotekoznawczych, w: Nauka o książce, bibliotece $i$ informacji we wspótczesnym świecie, red. merytor. M. Banacka, Warszawa 2003 , s. 12. 
dyscyplin, o ile odbywa się w sposób rzetelny, przy wykorzystaniu dorobku i jeśli jest to możliwe również metodologii innych nauk. Należy się bowiem zgodzić z B. Bieńkowską, iż skłonność do zasklepiania się środowisk naukowych „w kręgu własnych specjalności (np. historia, filologia, filozofia, socjologia), utrudnia przepływ wiedzy" ${ }^{\prime \prime}$.

${ }^{64}$ B. Bieńkowska, Zastosowania i konteksty wiedzy o ksiqżce, w: Wiedza o książce w nauce i dydaktyce. Konferencja Warszawa 16-17 listopada 1994, red. M. Kisilowska, J. Puchalski, D. Kuźmina, Warszawa 2000 , s. 65. 